\title{
A Supplementary Protein Food for Pregnant Women with Chronic Energy Deficiency to Improve Fetal Growth
}

\author{
Fajria Saliha Puspita Prameswari ${ }^{1}$, Sri Anna Marliyati ${ }^{*}$, Mira Dewi ${ }^{1}$ \\ ${ }^{1}$ Department of Community Nutrition, Faculty of Human Ecology, \\ IPB University, Bogor, 16680, Indonesia
}

\begin{abstract}
The aimed to analyze the effect of protein-sourced supplementary foods for pregnant women with CED to improve fetal growth. The pre-post study test involved 44 pregnant women with a Mid Upper Arm Circumference (MUAC) of $<23.5 \mathrm{~cm}$ in Bogor City, West Java. The subjects were divided into two groups, first was the PG group, consist of pregnant women who received the protein-sourced supplementary foods. The second was the PCG group where the pregnant women recieved the standard government supplementary food (GSF) for eight weeks. Data regarding the fetal growth was obtained using USG, the inidactor measured were the femur length and estimated fetal weight. The increase of femur length and estimated fetal weight were used as the fetal growth parameters. Analysis of Covariance was applied to obtain the effect of intervention by controlling other covariate variables. The result showed that the improvement of estimated fetal weight (EFW) and femur length (FL) in both groups were similar $(\mathrm{p}>0.05)$. Despite the fact that the PG group showed lower compliance compared to the PCG $(\mathrm{p}>0.05)$. The findings suggest that our protein-sourced supplementary foods had a similar effect with the GSF on fetal growth of pregnant women with CED.
\end{abstract}

Keywords: chronic energy deficiency, fetal growth, pregnancy, supplementary food

\section{INTRODUCTION}

The anabolic and catabolic processes during pregnancy leads to increase in maternal nutritional need to ensure optimal fetal growth (Brown 2005). Inadequate nutritional intake during pregnancy causes substantial implications and increases maternal and offspring risks of poor outcomes (Wu et al. 2012; Black \& Heidkamp 2018). Chronic energy deficiency (CED) is a common nutrition problem for pregnant women in the developing countries. In Indonesia, women with a mid-upper arm circumference (MUAC) of below $23.5 \mathrm{~cm}$ are classified as having CED (Kemenkes RI 2013). In 2007, the prevalence of CED among pregnant women was $13.6 \%$ and increased to $24.2 \%$ in 2013 , however it declined in 2018 to $17.3 \%$ (Kemenkes RI 2007; Kemenkes RI 2013; Kemenkes RI 2018a). According to WHO (1995), CED is considered as poor nutritional condition.

The main cause for maternal CED are inadequate intake of energy and protein during pregnancy. About $53.9 \%$ and $51.9 \%$ of pregnant women in Indonesia were deficient in energy and protein (Kemenkes RI 2018b). While, inadequate nutritional intake during pregnancy leads to fetal growth failure, IUGR (Intrauterine Growth Retardation), low birth weight (LBW), preterm delivery, and birth defects (Wu et al. 2012; Black $\&$ Heidkamp 2018). The prevalence of newborn with birth length $<48 \mathrm{~cm}$ had increased from $20.2 \%$ in 2013 to $22.7 \%$ in 2018 (Kemenkes RI 2013; Kemenkes RI 2018a). Short birth length may result in stunting, a growth failure in children under 5 years. Stunting is considered as public health nutritional problem, since the prevalence of stunting in Indonesia was $30.8 \%$ (Kemenkes RI 2018a). Several health problems may occur as the result of stunting and lead to reduction of individual productivity in the future (TNP2K 2017). Stunting prevention starts from the first 1,000 days of life which include nutrition during pregancy.

Maternal supplementary feeding during pregnancy can support the improvement of maternal nutritional status (Dewey 2016). Balanced energy-protein supplementation (protein $<25 \%$ of total energy in supplement) which given in the second trimester of pregnancy can significantly increase fetal weight, and if given at late pregnancy can improve fetal growth, increase birth weight and birth length, and also reduce the percentage of LBW up to $6 \%$. The

"Corresponding Author: +628121105760, email: anna_marliyati@yahoo.com 
protein content in supplementary food should be at least $12.3 \%$ to be efficient on improving fetal growth (Liberato et al. 2013). According to Imdad dan Bhutta (2012), balanced energyprotein supplementation is more effective on increasing birth weight and reducing LBW in pregnant women with poor nutritional status than pregnant women with normal nutritional status. Indonesian national program to fulfill nutritional needs of CED pregnant women has been done since 2016. The Ministry of Health in Republic of Indonesia distributes biscuits as supplementary food for pregnant women with CED (Kemenkes RI 2017). Thus, accessibility to the intervention is still a problem. Several studies about the efficacy of supplementary food CED pregnant women had beed conducted in Indonesia by measuring several indicators, such as hemoglobin levels (Sairuroh 2019), but none of it measure the fetal growth. This study aimed to determine the effect of protein-source supplementary foods given for pregnant women with CED on their fetal growth.

\section{METHODS}

\section{Design, location, and time}

This research was a pre-post test experimental study which was conducted from December 2018 to April 2019 and took place in 8 Community Health Centers in Bogor City. The research location was chosen based on the highest prevalence of maternal CED in Bogor according to Bogor City Public Health Office. Baseline and endline data collection were conducted in Klinik Medika Utama, Bogor. Ethical approval for this research was issued by the Ethics Committee for Research Involving Human Subjects, IPB University No:129/IT3.KEPMSM-IPB/SK/2018.

\section{Sampling}

The subjects of this research were pregnant women in the second trimester of pregnancy. The inclusion criterias were pregnant women aged 16-35 years old, Mid Upper Arm Circumference (MUAC) $<23.5 \mathrm{~cm}$, carried singleton pregnancy, and signed the informed consent. While the exclusion criterias were pregnant women whose allergic to eggs or nuts, had high blood pressure (diastolic blood pressure $\geq 90 \mathrm{mmHg}$ ) (WHO 2011), had high random blood glucose $(\geq 11.1$ $\mathrm{mmol} / \mathrm{L}$ ) (WHO 2013), and suffered from chronic disease.
Screening process was performed before the baseline data collection. Screening process was conducted two times due to inadequate number of subjects for both groups. The first screening process was done to collect subjects for the intervention group (PG) group and 39 women were selected to follow the procedure, however 7 women did not come to baseline data collection, resulting 32 women to continue the procedure. 5 women were excluded from this study because 4 women were pregnant $>7$ months and 1 woman had anembryonic pregnancy.

Meanwhile, the second screening process was done to collect subjects for the positive control group (PCG) and 25 women were selected to follow the procedure with 22 women continued the procedure since 3 women did not come to baseline data collection. 1 woman was excluded because she was $>7$ months pregnant. 48 women, with 27 women in PG and 21 women in PCG, were selected to follow the intervention period. Four subjects were dropped-out during the intervention period. 3 women in PG and 1 woman in PCG were dropped-out because they did not consume the intervention products for a week, resulting in 24 women in PG and 20 women in PCG to continue the intervention. Pregnant women with CED belong to critical group, thus treatment should be given, and hence we need the PCG. The sample size calculation was conducted based on the study of Kaseb et al. (2002).

\section{Procedure}

Screening process was conducted in an eight predetermined community health center. The designated subjects who fulfill the inclusion criteria were asked to come to the location of baseline data collection. Maternal characteristics were collected using questionnaire. Maternal anthropometric data, namely weight, height, and MUAC were measured on digital weight scale, stature meter, and measuring tape respectively. Fetal growth, indicated by femur length (FL) and estimated fetal weight (EFW) was measured with an ultrasonography (USG) and was compared to a standard fetal growth scheme (Kiserud et al. 2017). Finger prick blood sample for haemoglobin $(\mathrm{Hb})$ and random blood glucose level collection were performed using different lancets. The $\mathrm{Hb}$ was analyzed using HemoCue, while random blood glucose level was analyzed using a Glucometer. Maternal food intakes were 
estimated using $1 \times 24$ hours food recall which was performed every two weeks during the intervention period. Maternal food intake before the intervention was measured by food frequency questionnaire (FFQ).

Subjects were distributed into two groups, PG and PCG, and were obliged to consume the products, the high protein supplementary food and the government biscuits for 8 weeks. Subjects in $P G$ were given three types of protein-sourced supplementary foods in the form of snackbar (SB), instant powdered-drink (IPD), and instant cream soup (ICS), whereas subjects in PCG were given government supplementary food (GSF) in the form of biscuit. The products were given alternately, with SB to be given solely for the 1 st to 3rd week. And the addition of two other products were given as a combination with SB start from the 4th to 8th week. ICS and IPD were never given solely to the subjects, but always given as combination with SB. The average of protein content of the three products was $18.2 \%$ and this percentage meets the criteria of balanced energy-protein supplementary food according to Liberato et al. (2013). These products are also considered as protein-sourced food since the protein content is $>20 \%$ of nutrition label recommendation per $100 \mathrm{~g}$ products. The nutrient content of each supplementary food are shown in Table 1.

The subjects received new products once a week which were delivered directly to them. PG subjects received 14 packages of products and were requested to consume 2 packages per day, that equal to $100 \mathrm{~g}$ of supplemented food. Whereas, PCG subjects received 7 packages of product with 3 pieces of biscuits in each package, and were asked to consume one package per day. Each package of biscuits weighed $60 \mathrm{~g}$.

Tabel 1. Nutrient content of supplemented foods per 100 gram

\begin{tabular}{lcccc}
\hline \multirow{2}{*}{ Nutrient content } & \multicolumn{3}{c}{ Protein-sourced } & \\
\cline { 2 - 4 } & supplementary foods & GSF \\
\cline { 2 - 4 } & ICS & IPD & SB & \\
\hline Energy (kkal) & 432 & 423 & 447 & 487 \\
Protein (g) & 30.2 & 14.3 & 15.3 & 10.1 \\
Fat (g) & 14.2 & 9.9 & 21.4 & 20.9 \\
Carbohydrate (g) & 48.6 & 70.5 & 52.0 & 66.7 \\
ICS: Instant cream soup; IPD: Instant powdered-drink; SB: & Snackbar; GSF: Government supplementary food &
\end{tabular}

The products' consumption was monitored using a compliance form to record daily products consumption. The compliance form, used package, and product-waste should be returned once a week. After eight weeks, endline data collection was performed.

\section{Data analysis}

The collected data was processed and analyzed by using Microsoft Excel 2013 and SPSS Version 16.0. Maternal characteristics were analyzed descriptively. Independent t-test or Mann-Whitney test was performed to analyze the difference between the two groups. Paired T-test was performed to analyze the difference of fetal growth after intervention. Adjusted ANCOVA analyses was performed to determine the effect of intervention on fetal growth by adjusting the covariate variables.

\section{RESULTS AND DISCUSSION}

\section{Maternal characteristics}

Maternal characteristics, namely maternal age, age of gestation, gap between pregnancy, parity, history of stillbirth, pre-pregnancy body mass index (BMI), and MUAC were examined and none showed any significant difference (Table 2).

Most subjects in the PG and PCG were aged between $17-25$ years with a mean maternal aged of $25.92 \pm 4.4$ years and $23.95 \pm 3.6$ years, respectively. The maternal age range with the lowest risk is 20-30 years (Bellieni 2016). Teen pregnancies increases the risk of pre-term labor, Low Birth Weight (LBW), post-partum hemorrhage, and maternal or infant mortality (Kemenkes RI 2015). The gestation age in both groups were ranged between 19-21 weeks. During this period, accelerated fetal growth, structural development, and the beginning of functional activity start to occur (Wiknjosastro et al. 1992).

Most of the subjects had a gap between pregnancy of more than two years, this in line to the WHO recommendation (2006). Almost all of the subjects belonged to the nullipara and primipara. Mothers who have had $>5$ parity have higher risks of fetal macrosomia, diabetes mellitus, and pregnancy induced hypertension (Alsammani \& Ahmed 2015). A few of subjects had experienced miscarriage. Teen pregnancies, 
as well as advanced maternal age, and maternal malnutrition are the risk factors of miscarriage (Metwally et al. 2010). Mean maternal prepregnancy BMI in the PG and PCG groups were $18.82 \pm 2.2 \mathrm{~kg} / \mathrm{m} 2$ dan $18.7 \pm 2.1 \mathrm{~kg} / \mathrm{m} 2$, respectively. Despite all mothers involved in the study had a MUAC of below $23.5 \mathrm{~cm}$, only around half were categorized as underweight based on their BMI in both groups. According to Fakier et al. (2017) MUAC can significantly define maternal nutritional status up to 30 weeks of pregnancy.

\section{Maternal nutrient intake (other than supplemented foods)}

Mean nutrients intake were obtained using the 24 hours food recalls which were conducted four times through intervention period. All mean nutrients intake of subjects in both groups were below the dietary recommendation intake for pregnant women (AKG 2013) the subjects nutrient adequacy level was below $70 \%$. The mean intake of all nutrients in both groups did not differ significantly (Table 3 ).

The mean energy intake in both groups were below the daily recommendation intake for pregnant women, which was 2,550 kkal per day. The subjects' mean energy intake in both groups were approximately 1,600 kkal. The level of energy intake during the gestational period correlated significantly with the infant birth weight. Maternal energy intake of below 1,500 kkal will result in infant LBW (Durrani \& Rani 2011). The subjects' low energy intake was caused by low frequency in food consumption, which was less than 3 times a day. Low frequent food intake during pregnancy increases the risk of maternal CED (Engidaw et al. 2019).

The mean protein intake of the subjects in both groups were approximately $55 \mathrm{~g}$ per day, while the recommendation of protein intake for pregnant women is $76 \mathrm{~g}$ per day. According

Table 2. Maternal characteristics in intervention group and positive control group

\begin{tabular}{|c|c|c|c|}
\hline \multirow[b]{2}{*}{ Indicators } & \multicolumn{2}{|c|}{ Group } & \multirow[b]{2}{*}{$\mathrm{p}$ value } \\
\hline & $\begin{array}{c}\mathrm{PG} \\
(\mathrm{n}=24)\end{array}$ & $\begin{array}{c}\text { PCG } \\
(\mathrm{n}=20)\end{array}$ & \\
\hline Maternal age (years) & $25.92 \pm 4.4$ & $23.95 \pm 3.6$ & 0.118 \\
\hline$<17$ years $(\mathrm{n}, \%)$ & $1(4.2)$ & $0(0.0)$ & \\
\hline $17-25$ years $(\mathrm{n}, \%)$ & $13(54.2)$ & $14(70.0)$ & \\
\hline$>25$ years $(\mathrm{n}, \%)$ & $10(41.6)$ & $6(30.0)$ & \\
\hline Gestation age (weeks) & $19.7 \pm 4.1$ & $20.9 \pm 3.8$ & 0.313 \\
\hline Pregnancy gap ${ }^{2}$ & & & 0.408 \\
\hline$<24$ months $(\mathrm{n}, \%)$ & $5(20.8)$ & $3(15.0)$ & \\
\hline$>24$ months $(\mathrm{n}, \%)$ & $10(41.6)$ & $7(35.0)$ & \\
\hline $1^{\text {st }}$ pregnancy $(\mathrm{n}, \%)$ & $9(37.6)$ & $10(50.0)$ & \\
\hline Parity $^{2}$ & & & 0.550 \\
\hline Nullipara (n,\%) & $10(41.6)$ & $9(45.0)$ & \\
\hline Primipara $(\mathrm{n}, \%)$ & $10(41.6)$ & $10(50.0)$ & \\
\hline Multipara (n,\%) & $4(16.7)$ & $1(5.0)$ & \\
\hline Miscarriage $^{2}$ & & & 0.526 \\
\hline Yes $(\mathrm{n}, \%)$ & $4(16.7)$ & $2(10.0)$ & \\
\hline No $(\mathrm{n}, \%)$ & $20(83.3)$ & $18(90.0)$ & \\
\hline Pre-pregnancy BMI $\left(\mathrm{kg} / \mathrm{m}^{2}\right)$ & $18.82 \pm 2.2$ & $18.7 \pm 2.1$ & 0.865 \\
\hline Underweight (n, \%) & $11(45.8)$ & $11(55.0)$ & \\
\hline Normal (n, \%) & $13(54.2)$ & $9(45.0)$ & \\
\hline MUAC $(\mathrm{cm})$ & $21.35 \pm 1.2$ & $21.28 \pm 1.3$ & 0.848 \\
\hline
\end{tabular}

Independent T-test: ${ }^{2}$ Mann-Whitney; Significant at $\mathrm{p}<0.05$; PG: Intervention Group; PCG: Positive Control Group; MUAC: Mid Upper Arm Circumference 
to Kominiarek \& Rajan (2016), the minimum amount of daily protein intake to assure optimal fetal growth during pregnancy is $60 \mathrm{~g}$ per day. The low protein intake happened because of low intake of protein-sourceds foods consumption as obtained through FFQ. This low protein intake can lead to impaired fetal growth and development, cretinism, and IUGR (intrauterine growth restriction) (Wu et al. 2012).

According to Kemenkes RI (2014), the total fat intake should comprise $20-30 \%$ of the daily calories intake. The mean of maternal fat adequacy level for both groups were higher than the recommendation. On the other hand, the total carbohydrate intake should comprise $45-65 \%$ of daily calories intake (Kemenkes RI 2014). The mean maternal carbohydrate adequacy level of both groups were considered to be sufficient. This condition showed that all of the subjects had low energy intake, with fat and carbohydrate as the major macronutrient sources for their daily calories intake.

The recommended type of fatty acid during pregnancy are docosahexaenoic acid and eicosapentaenoic acid, which are beneficial for fetal brain development and proper functioning of the retina (Danielewicz et al. 2017). The major fat source of subjects were saturated fatty acid because most of the subjects consumed fried food in their daily food intake. Frequent high saturated fats consumption during pregnancy causes maternal and infant implications, such as anemia, impaired fetal growth and development, and LBW and/or excess weight (Santana et al. 2015). A study conducted using animal model showed that maternal high saturated fats consumption increased the plasma total cholesterol and low density lipoprotein cholesterol concentrations in the offsprings (Chechi \& Cheema 2006).

Complex carbohydrate is recommended for pregnant women to improve the function of gut microbiome (Danielewicz et al. 2017). Maternal carbohydrate source in this study were mostly simple carbohydrate in the form of white rice or flour-based food. According to Starling et al. (2017), pregnant women with high intake of eggs, starchy vegetables, and nonwhole grains was correlated with higher maternal fasting glucose and greater newborn adiposity, than the pregnant women with high intake of whole grains, poultry, nuts, and cheese.

\section{Compliance level of supplementary foods consumption}

Maternal compliance level in PG was lower than PCG and the difference was statistically significant (Table 4). The low compliance level in PG group happened because there were three variances of products with diverse tastes and serving methods. Meanwhile the GSF which were given to subjects in PCG was more efficient and easy to be consumed, so the compliance level was higher.

The compliance level of each products in the PG were described in Figure 1. Low compliance level on ICS and IPD consumption might happened because of subjects' infamiliarity to consume those products as supplementary foods, especially ICS which was uncommon to be consumed in Indonesia. Cream soup should be consumed as an appetizer or main course (Setiawati et al. 2017). The subjects could not consumed the entire ICS since it was way too fulfilling if consumed as supplementary food.

Table 3. Mean nutrient intake and adequacy level of subjects in intervention group and positive control group

\begin{tabular}{|c|c|c|c|c|}
\hline \multirow{2}{*}{ Nutrients } & \multirow{2}{*}{ Intake and adequacy level } & \multicolumn{2}{|c|}{ Group } & \multirow{2}{*}{$\mathrm{p}$-value } \\
\hline & & PG & PCG & \\
\hline \multirow[t]{2}{*}{ Energy } & Intake (kkal) & $1,619 \pm 480$ & $1,687 \pm 436$ & 0.631 \\
\hline & Adequacy (\%) & $63.5 \pm 18.8$ & $66.1 \pm 17.1$ & 0.629 \\
\hline \multirow[t]{2}{*}{ Protein $^{2}$} & Intake $(\mathrm{g})$ & $56.3 \pm 17.7$ & $55.5 \pm 13.8$ & 0.962 \\
\hline & Adequacy (\%) & $74.1 \pm 23.3$ & $73.0 \pm 18.2$ & 0.953 \\
\hline \multirow[t]{2}{*}{ Fat } & Intake (g) & $55.0 \pm 18.2$ & $61.7 \pm 19.4$ & 0.241 \\
\hline & Adequacy (\%) & $30.6 \pm 4.1$ & $32.8 \pm 4.2$ & 0.240 \\
\hline \multirow[t]{2}{*}{ Carbohydrate $^{2}$} & Intake (g) & $224.6 \pm 70.0$ & $234.4 \pm 64.8$ & 0.580 \\
\hline & Adequacy $(\%)$ & $55.4 \pm 4.5$ & $55.5 \pm 3.4$ & 0.580 \\
\hline
\end{tabular}

Independent T-test: ${ }^{2}$ Mann-Whitney; Significant at $\mathrm{p}<0.05$; PG: Intervention group; PCG: Positive control group 
IPD should be dissolved by hot water. However, although it had been already dissolved by hot water, it still had thick texture and notentirely dissolved, so it contained residual which stayed in the mouth and left certain after taste after being swallowed. Similar with the IPD, the ICS had the same problems and resulted in low compliance level. Moreover, ICS was uncommon for the subjects, so majority of the subjects disliked the product. The highest compliance of protein sourced supplementary foods was from the $\mathrm{SB}$, since the product was more efficient to be served and the taste was also more preferable than the others. Figure 1 Compliance level of each supplemented foods in PG.

\section{Effect of protein-sourced supplementary foods on fetal growth}

Fetal growth was determined by using two indicators, femur length (FL) and estimated fetal weight (EFW). Table 5 indicated the average growth of fetuses in each gestation week. Low birthweight may happened due to intrauterine growth restriction, preterm delivery, or both. Birthweight is also a determinant risk of noncommunicable diseases occurence, with cardiovascular disease, type II diabetes mellitus, and obesity as the prominent evidences. Fetal growth observation should be done during pregnancy period as an early detection of imbalanced fetal growth. According to Kiserud et al. (2017) the fetal growth in both groups were already in accordance with the current gestation week, however there was no difference in both measurement of indicators in both groups.

The FL and EFW in both groups had improved significantly at the endline data collection (Table 6). However, the difference in both groups were not significant. Thus the PG

Table 4 Subjects distribution according to level of compliance

\begin{tabular}{lccc}
\hline \multirow{2}{*}{ Compliance } & \multicolumn{2}{c}{ Group } & \multirow{2}{p}{} \\
\cline { 2 - 3 } & $\begin{array}{c}\text { PG } \\
(\mathrm{n}=24)\end{array}$ & $\begin{array}{c}\text { PCG } \\
(\mathrm{n}=20)\end{array}$ & \\
\hline & $65.0 \pm 9.1$ & $85.3 \pm 2.6$ & $0.000^{*}$ \\
High $(\geq 70 \%)$ & $7(30.4)$ & $17(85.0)$ & \\
Moderate (50-70\%) & $14(56.6)$ & $1(5.0)$ & \\
Low (<50\%) & $3(17.0)$ & $2(10.0)$ & \\
$\begin{array}{l}\text { Independent T-test: Significant at } \mathrm{p}<0.05 ; \text { PG: Intervention } \\
\text { group; PCG: Positive control group }\end{array}$
\end{tabular}

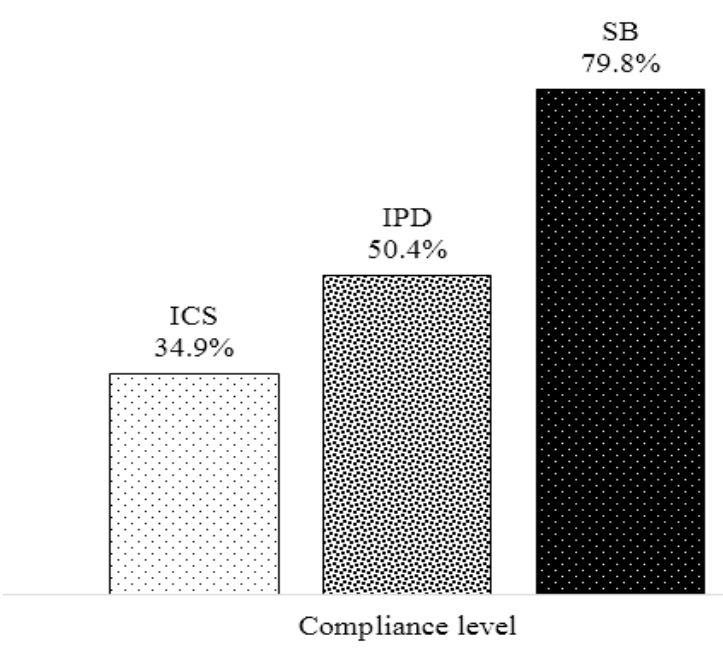

Figure 1. Compliance level of each supplemented foods in PG

had a similar effect with GSF in the PCG on fetal growth regardless of its lower compliance. After the covariate variables were adjusted using ANCOVA analysis, the result also showed no significant effect of the two supplementary foods on fetal growth.

The small impact of the supplementary food on fetal growth may occur because of the short intervention period and low compliance to the supplements. This result was similar to Nahar et al. (2009) who reported that small impact of supplementary food on maternal weight gain, and the difference could be explained by the time of supplementation starts, compliance, scheduled monitoring and supervision, also the nutrient content of the supplements. The compliance level in PG was significantly lower than the PCG and resulted on the products' nutrient contents were partially consumed. However, it can be assumed that if the protein-sourced supplementary foods has a better compliance, it will give better result than the GSF. A better compliance of supplemented food showed an increase in infant mean birth weight up to $180 \mathrm{~g}$ (Tabrizi et al. 2019). Malnourished and anemic women tended to have higher proportions on LBW (Mahajan et al. 2009), However, intervention to improve their nutritional status such as administration of supplementary food showed more positive effects on lowering LBW and preterm births in this group (Tabrizi et al. 2019).

Based on the adjusted ANCOVA analysis, the covariate factors which were affecting the fetal growth were the maternal height for FL $(p<0.05)$ and the gestational age, both for FL and 
Table 5. Average growth of fetuses in each gestation week in both groups

\begin{tabular}{llcccc}
\hline \multirow{2}{*}{ Group } & Fetal measurement & \multicolumn{4}{c}{ Gestation week } \\
\cline { 3 - 6 } & & $21-25$ & $26-30$ & $31-35$ & $36-38$ \\
\hline PG & Estimated fetal weight (g) & $567.5 \pm 194.4$ & $1,290,7 \pm 300.0$ & $222.8 \pm 349.9$ & $2,540 \pm 56.6$ \\
& Femur length (mm) & $41.1 \pm 3.6$ & $54.4 \pm 3.5$ & $64.7 \pm 3.7$ & $70.9 \pm 0$ \\
& Total & 4 & 6 & 12 & 2 \\
PCG & Estimated fetal weight (g) & 388 & $1,187 \pm 302.7$ & $1,956,4 \pm 330.1$ & $2,974 \pm 185.3$ \\
& Femur length (mm) & 32.9 & $52.9 \pm 4.6$ & $62.6 \pm 3.6$ & $73.9 \pm 1.6$ \\
& Total & 1 & 5 & 12 & 2 \\
\hline PG: Intervention group; PCG: Positive control group & & & &
\end{tabular}

EFW ( $<<0.05)$. This study was started when the subjects were in the 2 nd trimester of pregnancy and ended in the 3 rd trimester of pregnancy. Maternal height gave the information on genetic potentials of the offsprings. Fetal FL was found to be positively related with maternal height on the last stage of pregnancy (29 weeks to birth) (Wills et al. 2010). Another study also showed similar effect and stated that positive relation between maternal height and fetal FL on singleton pregnancy at 25 weeks of pregnancy (Goldenberg et al. 1993).

Both of the fetal growth indicators in this study were positively correlated with gestational age. Women experienced hormone secretion changes during pregnancy which resulted on the alteration of carbohydrate, fat, and protein function. Adaptive responses were developed during pregnancy to ensure sufficient nutrient for fetus, regardless of the maternal nutritional status (Williamson 2006). Fetal growth increase rapidly at the last trimester of pregnancy, marked by the rapid growth and improvement of brain and organs functions (Santrock 2012). However, poor outcomes might still be present both for mothers and the offsprings, such as increase of maternal and infant mortality, preterm delivery, and infant LBW, if the maternal nutritional needs still not be fulfilled (Erick 2008; Medhin et al. 2010).

Table 6. Effect of variation of protein-sourced supplementary foods on fetal growth

\begin{tabular}{|c|c|c|c|}
\hline \multirow{2}{*}{ Growth } & \multicolumn{2}{|c|}{ Group } & \multirow{2}{*}{ p-value } \\
\hline & PG & PCG & \\
\hline \multicolumn{4}{|l|}{ Femur length (mm) } \\
\hline Baseline & $31.28 \pm 12.2$ & $33.97 \pm 12.4$ & \\
\hline Endline & $58.70 \pm 10.0$ & $59.8 \pm 9.4$ & \\
\hline p-value ${ }^{1}$ & $0.000^{*}$ & $0.000^{*}$ & \\
\hline$\Delta^{2}$ & $27.42 \pm 5.0$ & $25.85 \pm 6.1$ & 0.357 \\
\hline Adjusted Ancova ${ }^{3}$ & $(26.692)$ & $(26.722)$ & 0.982 \\
\hline \multicolumn{4}{|l|}{ Estimated fetal weight (g) } \\
\hline Baseline & $408.08 \pm 297.46$ & $474.65 \pm 270.89$ & \\
\hline Endline & $1,740,29 \pm 743.09$ & $1,787,4 \pm 669.6$ & \\
\hline p-value ${ }^{1}$ & $0.000^{*}$ & $0.000^{*}$ & \\
\hline$\Delta^{2}$ & $1,332,21 \pm 515.9$ & $1,312,75 \pm 487.0$ & 0.899 \\
\hline Adjusted Ancova ${ }^{3}$ & $(1,250)$ & $(1,411)$ & 0.293 \\
\hline
\end{tabular}

${ }^{2}$ Independent T-test: Significant at $\mathrm{p}<0.05$

${ }^{3}$ ANCOVA: Significant at $\mathrm{p}<0.05$; Covariate: Maternal age, maternal height, maternal pre-pregnancy BMI, gestational age gain, maternal weight gain, parity

PG: Intervention Group; PCG: Positive control group 


\section{CONCLUSION}

The protein-sourced supplementary foods had lower compliance level than GSF, however both intervention showed similar effects on fetal growth (adjusted ANCOVA) ( $>>0.05)$. The main factors that affected the fetal growth were gestational age and maternal height. Optimal nutritional intake and supplementary food consumption based on the recommendations for CED pregnant women can improve fetal growth. Improvement on the organoleptic aspects of the current product may lead to increase in the compliance level, hence it may show better result on fetal growth. In addition, longer intervention period and addition of micronutrients to the product may also support improvement on fetal growth indicators.

\section{ACKNOWLEDGEMENT}

This research was supported by Kementerian Kesehatan Republik Indonesia (Kemenkes RI). We thank the health workers in Puskesmas Gang Kelor, Puskesmas Semplak, Puskesmas Merdeka, Puskesmas Sindang Barang, Puskesmas Pasir Mulya, Puskesmas Pancasan, Puskesmas Kayu Manis, Puskesmas Tanah Sareal, and Puskesmas Pondok Rumput Kota Bogor. Also the cadres in the involved antenatal care services. The authors have no conflict of interest.

\section{REFERENCES}

Alsammani MA, Ahmed SR. 2015. Grand multiparity: Risk factors and outcome in a tertiary hospital: A comparative study. Mater Sociomed. 27(4): 244-247. DOI: 10.5455/msm.2015.27.244-247.

Bellieni C. 2016. The best age for pregnancy and undue pressures. J Fam Reprod Health. 10(3):104-107.

Black ER, Heidkamp R. 2018. Causes of stunting and preventive dietary interventions in pregnancy and early childhood. Nestlé Nutr Inst Workshop Ser 89:105-113. https://doi.org/10.1159/000486496.

Brown JE 2005. Nutrition through the Life Cycle 2nd Ed. Belmont: Thomson Wadsworth.

Chechi K, Cheema SK. 2006. Maternal diet rich in saturated fats deleterious effects on plasma lipids of mice. Exp Clin Cardiol. 11(2):129-135.

Danielewicz H, Myszczyszyn G, Dębińska A, Myszkal A, Boznański A, Hirnle L. 2017. Diet in pregnancy-more than food. Eur J Pediatr 176:1573-1579. https://doi. org/10.1007/s00431-017-3026-5.

Dewey KG. 2016. Reducing stunting by improving maternal, infant, and young child nutrition in regions such as South Asia: Evidence, challenges and opprtunities. Matern Child Nutr 12:27-38. DOI: $10.1111 / \mathrm{mcn} .12282$

Durrani AM, Rani A. 2011. Effect of maternal dietary intake on the weight of the newborn in Aligarh city, India. Niger Med J. 52(3):177-181.doi:10.4103/ 03001652.86132 .

Engidaw MT, Gebremariam AD, Tiruneh SA, Asnakew DT, Abate BA. 2019. Chronic energy deficiency and its associated factors among lactating women in Debre Tabor general hospital, Northcentral Ethiopia. Journal of Family Medicine and Health Care 5(1):1-7.doi:10.11648/j. jfmhc.20190501.11.

Erick M. 2008. Nutrition during pregnancy and lactation. In: Mahan LK, Stump SE, editor. Krause's Food and Nutrition Theraphy 12th Ed. Vancouver: Saunders Elsevier Inc.

Fakier A, Petro G, Fawcus S. 2017. Mid-upper arm circumference: A surrogate for body mass index in pregnant women. S Afr Med J 107(7):606-610. https://doi.org/10.7196/ SAMJ.2017.v107i7.12255.

Goldenberg RL, Davis RO, Cliver SP, Cutter GR, Hoffman HJ, Dubard MB. 1993. Maternal risk factors and their influence on fetal anthropometric measurements. Am J Obstet Gynecol 168(4):1197-1205. https:// doi.org/10. 1016/0002-9378(93)90369-t.

Imdad A, Bhutta ZA. 2012. Maternal nutrition and birth outcomes: Effect of balanced proteinenergy supplementation. Paediatr Perinat Epidemiol 26(1):178-190. https://doi. org/10.1111/j.1365-3016.2012.01308.x.

[Kemenkes RI] Kementerian Kesehatan Republik Indonesia. 2007. Riset Kesehatan Dasar. Jakarta: Kemenkes RI.

[Kemenkes RI] Kementerian Kesehatan Republik Indonesia. 2018a. Riset Kesehatan Dasar. Jakarta: Kemenkes RI 
[Kemenkes RI] Kementerian Kesehatan Republik Indonesia. 2018b. Kementerian Kesehatan Republik Indonesia. Buku Saku Pemantauan Status Gizi Tahun 2017. Jakarta: Kemenkes RI.

[Kemenkes RI] Kementerian Kesehatan Republik Indonesia. 2013. Riset Kesehatan Dasar. Jakarta: Kemenkes RI.

[Kemenkes RI] Kementerian Kesehatan Republik Indonesia. 2014. Pedoman Gizi Seimbang. Jakarta: Kemenkes RI.

[Kemenkes RI] Kementerian Kesehatan Republik Indonesia. 2015. Infodatin: situasi kesehatan reproduksi remaja. http://www. depkes.go.id/article/view/15090200001/ situasi-kesehatan-reproduksi-remaja.html. [Accessed 19 May 2015].

[Kemenkes RI] Kementerian Kesehatan Republik Indonesia. 2017. Petunjuk Teknis Pemberian Makanan Tambahan (BalitaIbu Hamil-Anak Sekolah). Jakarta: Kemenkes RI.

Kaseb F, Kimiagar M, Ghafarpoor M, Valaii N. 2002. Effect of traditional food supplementation during pregnancy on maternal weight gain and birthweight. Int J Vitam Nutr Res 72(6):389-393. https:// doi.org/10.1024/0300-9831.72.6.389.

Kiserud T, Piaggio G, Carroli G, Widmer M, Carvalho J, Jensen LN, Giodano D, Cecatti JG, Aleem HA, Talegawkar SA et al. 2017. The world health organization fetal growth chart: A multinational longitudinal study of ultrasound biometric measurements and estimated fetal weight. PLoS Med 14(1):1-36. https://doi.org/10.1371/ journal.pmed.1002220.

Kominiarek MA, Rajan P. 2016. Nutrition recommendations in pregnancy and lactation. Med Clin N Am 100(6):1199$1215 . \quad$ https://doi.org/10.1016/ j.mena.2016.06.004.

Liberato SC, Singh G, Mulholland K. 2013. Effects of protein energy supplementation during pregnancy on fetal growth: A review of the literature focusing on contextual factors. Food Nutr Res 57(1):20499. https://doi.org/10.3402/fnr.v57i0.20499

Mahajan SD, Singh S, Shah P, Gupta N, Kochupillai N. 2009. Effect of maternal malnutrittion and anemia on endocrine regulation of fetal growth. Endocrine
Research 30(2):189-203. https://doi. org/10.1081/ERC-200027380.

Medhin G, Hanlon C, Dewey M, Alem A, Tesfaye F, Worku B, Tomlinson M, Prince M. 2010. Prevalence and predictors of undernutrition among infants aged six and twelve months in Butajira, Ethiopia: The P-Mamie birth cohort. BMC Public Health 10(27):1-15. https://doi.org/10.1186/1471-2458-10-27.

Metwally M, Saravelos SH, Ledger WL, $\mathrm{Li}$ TC. 2010. Body mass index and risk of miscarriage in women with recurrent miscarriage. Fertil Steril 94(1):290-295. https://doi.org/10.1016/j. fertnstert.2009.03.021.

Nahar S, Mascie-Taylor CN, Begum HA. 2009. Impact of targeted food supplementation on pregnancy weight gain and birth weight in rural Bangladesh: An assessment of the Bangladesh Integrated Nutrition Project (BINP). Publ Health Nutr 12(08):1205-1212. https://doi. org/10.1017/S1368980008003765.

Sairuroh, Rahfiludin MZ, Kartasurya MI . 2019. Dampak pemberian biskuit pada ibu hamil berisiko kekurangan energi kronis terhadap kadar hemoglobin. MKMI 18(2):1-6.

Santana JDM, Queiroz VADO, Brito SM, Santos DBD, Assis AMO. 2015. Food consumption patterns during pregnancy: a longitudinal study in a region of the North East of Brazil. Nutr Hosp 32(1):130-138. http://dx.doi.org/10.3305/ nh.2015.32.1.8970.

Santrock JW. 2012. Life-span Development 13th Ed: Perkembangan Masa Hidup Jilid 1. Jakarta: Erlangga.

Setiawati T, Sudewi, Mahmudatussa'adah A. 2017. Sweet potato cream soup sebagai alternatif bisnis makanan sehat. Jurnal Kompeten Teknik 9(1):1-6. https://doi. org/10.15294/jkomtek.v9i1.12184.

Starling AP, Sauder KA, Kaar JL, Shapiro ALB, Siega-Riz AM, Dabelea D. 2017. Maternal dietary patterns during pregnancy are associated with newborn body composition. J Nutr 147:1334-1339. https://doi.org/10.3945/jn.117.248948.

Tabrizi JS, Asghari A, Pourali F, Kousha H, Nikniaz L. 2019. Effects of food supplementation during pregnancy on maternal weight gain, hemoglobin levels 
and pregnancy outcomes in Iran. Matern Child Health J 23(2): 258-264. https://doi. org/10.1007/s10995-018-2648-1.

[TNP2K] Tim Nasional Percepatan Penanggulangan Kemiskinan. 2017. 100 Kabupaten/Kota Prioritas untuk Intervensi Anak Kerdil (Stunting). Jakarta: Sekretariat Wakil Presiden RI.

[WHO] World Health Organization. 1995. Maternal Anthropometry and Pregnancy Outcomes: A WHO Collaborative Study. Geneva: World Health Organization.

[WHO] World Health Organization. 2006. HTSP 101: everything you want to know about healthy timing and spacing of pregnancy. http://www.who.int/pmnch/topics/ maternal/ htsp101.pdf. [Accressed 19 May 2019].

[WHO] World Health Organization. 2011. WHO Recommendations for Prevention and Treatment of Pre-eclampsia and Eclampsia. Geneva: World Health Organization.

[WHO] World Health Organization. 2013. Diagnostic Criteria and Classification of HyperglycemiaFirstDetected in Pregnancy. Geneva: World Health Organization.
[WHO] World Health Organization. 2017. Balanced energy and protein supplementation during pregnancy. eLENA. http://www. who.int/elena/titles/ energy_protein_pregnan cy/en/. [Accessed 16 October 2018].

Wiknjosastro H, Saifuddin AB, Rachimhadhi T. 1992. Ilmu Kebidanan. Jakarta: Yayasan Bina Pustaka Sarwono Prawirohardjo.

Williamson CS. 2006. Nutrition in pregnancy. Nutr Bull 31(1):28-59. https://doi. org/10.1111/j.1467-3010.2006.00541.x.

Wills AK, Chinchwadkar MC, Joglekar CV, Natekar AS, Yajnik CS, Fall CHD, Kinare AS. 2010. Maternal and paternal height and BMI and patterns of fetal growth: The pune maternal nutrition study. Early Hum Dev 86(9):535-540. https://doi. org/10.1016/j.earlhumdev.2010.07.002.

Wu G, Imhoff-Kunsch B, Girard AW. 2012. Biological mechanisms for nutritional regulation of maternal health and fetal development. Paediatr Paediatr Perinat Epidemiol 26(1):4-26. https://doi. org/10.1111/j.1365-3016.2012 .01291.x. 